\title{
PALABRAS DE HOMENAJE Y DESPEDIDA DE LA DRA. ANA KUROKI CON MOTIVO DE SU JUBILACIÓN Y ENTREGA DE PLACA RECORDATORIA.
}

Señores amigos, compañeros y colegas: Nos reunimos hoy aquí para rendir homenaje de despedida de su vida activa asistencial en nuestro hospital a nuestro colega que ha alcanzado su situación de retiro.

Hoy que me veo con una gran responsabilidad de dirigirme a ustedes estimados colegas para dar algunas palabras alusivas del adiós administrativo a la colega Ana María Kuroki Ishii.

Esta noche quiero iniciar agradeciendo a todos los presentes por participar en esta reunión, sin embargo se me hace difícil encontrar palabras suficientes y adecuadas, pero lo que puedo identificar es que nos apena ya no tener que ver a la Dra Kuroki, trabajando con nosotros en el cuidado de la mujer peruana, ya no la veremos llegar temprano y verla en el marcador antes de las 8 de la mañana y más allá de las 8 de la noche, ya no la veremos coordinando actividades, como siempre la hemos visto donde ha trabajado en los Hospitales, Universidad, Colegio Médico, también no olvidamos también su participación en desfiles en nuestra ciudad y de buscar como colaborar con el enfermo. Hay buenas historias de ella con nosotros y con los que no están trabajando me refiero al Dr. SOLORZANO, PONCE y GARAMENDI, estamos muy agradecidos por su tiempo y trabajo realizado brindado salud a los pacientes de nuestro hospital,.

En el repaso de su vida profesional y haciendo un balance de ella, deja en evidencia o de manifiesto la personalidad de docente, de excelente participación como ginecóloga sentimos para nuestro servicio que estamos perdiendo una gran profesional, también por la dimensión humana. Como persona Ana Kuroki deja entre nosotros un gran vacío, nostalgia pero esta despedida la hacemos con mucha emoción.

Con gran energía ANA KUROKI culmina una gran etapa en su vida de servicio en el Hospital Santa María del Socorro de Ica, Perú. Esta noche queremos despedirla con todo el afecto y gratitud por su compañerismo, su esfuerzo y por las enseñanzas que de una u otra forma nos deja a su paso.

Este presente es un recuerdo que le brindamos sus compañeros al culminar su actividad asistencial y como demostración a una vida transcurrida bajo el signo de responsabilidad y gran trabajo. Todos sus colegas le deseamos sinceramente y de corazón que siga disfrutando largos años de salud, vitalidad y juventud espiritual con la que ahora la vida la recompensa y que constituirá la verdadera envidia para muchos de nosotros.

Ica, 17 junio de 2018

Dr. Jorge Ybaseta Medina

Jefe de Departamento de Gineco-obstetricia 


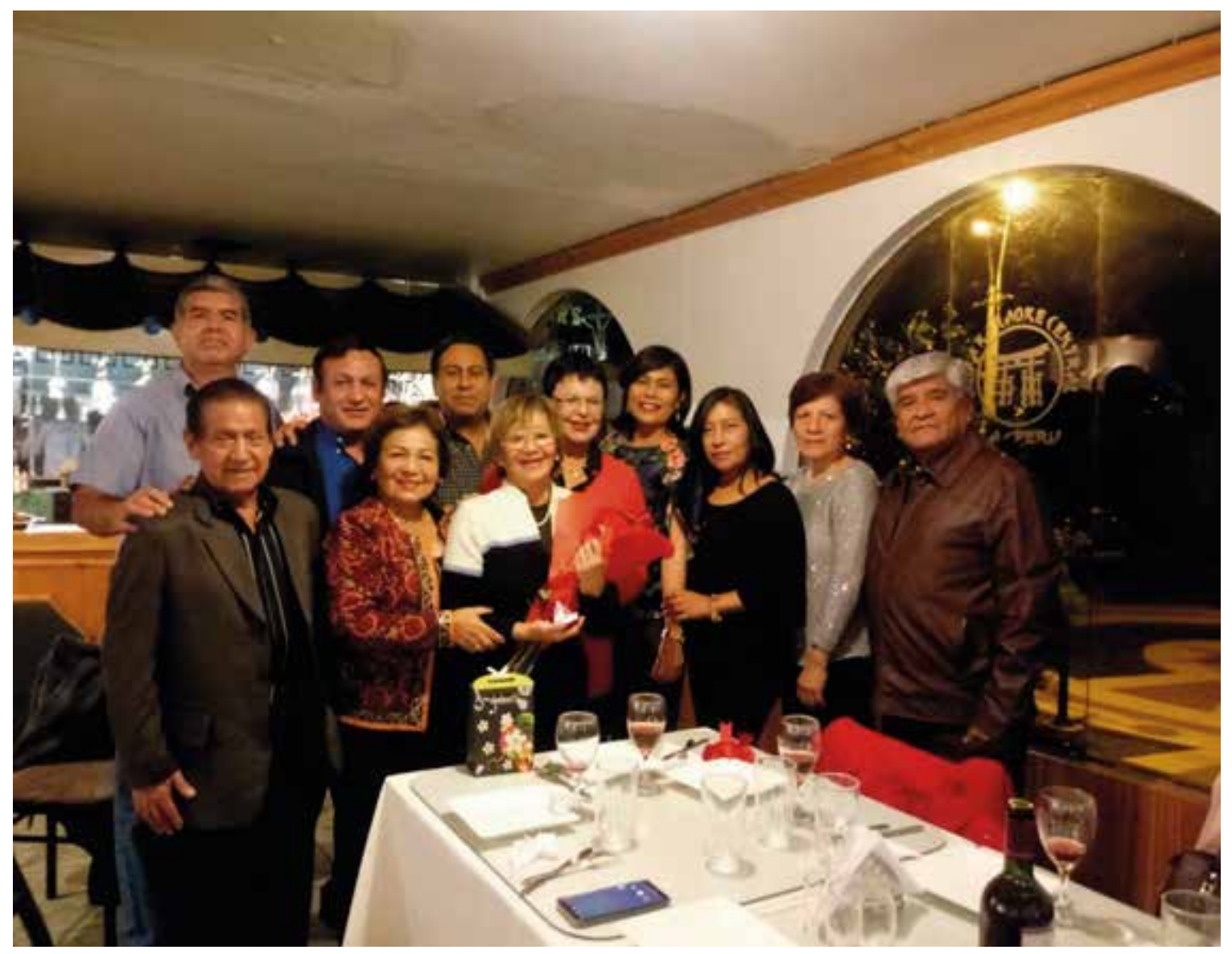

Figura 1. Homenaje de despedida a la Dra. Ana María Kuroki Ishii tras el cese de sus funciones asistenciales en el Hospital Santa María del Socorro de Ica, Perú. 